\title{
An Integrated Theory of Thinking and Speaking that Draws on Vygotsky and Bakhtin/Vološinov
}

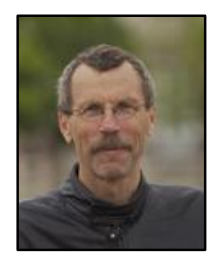

Wolff-Michael Roth

University of Victoria, Canada

\begin{abstract}
Vygotsky's social-psychological theory of human development and Bakhtin/Vološinov's theory of language and the dialogical nature of thought have received increasing interest in the educational research literature but tend to remain unrelated even where co-citation occurs. In this article, I first present a model that integrates the fundamentally common features in the two approaches and present a table with the correspondences of the theoretical terms across four European languages; the model thereby integrates the psychological and sociological dimensions at the heart of the two approaches. I then articulate and elaborate on six main issues that are relevant to and have implications for research: (a) sensual life as integrative unit, (b) self-movement and development, (c) the nested relations between activity and living utterance, (d) signification, (e) vernacular as the origin and locus of development, and (f) unit analysis.
\end{abstract}

Keywords: Vygotsky; Bakhtin circle; cultural-historical activity theory; sociocultural theory; socio-historical theory; dialogism; materialist dialectics; unit analysis

Wolff-Michael Roth is Lansdowne Professor of Applied Cognitive Science in the Faculty of Education at the University of Victoria. His research is concerned with knowing and learning across the life span, especially as it relates to mathematics and science. His research approach is transdisciplinary, and he publishes his research in many different scholarly fields. Recent publications include What First-Person Method (Sense, 2012), Passibility: At the Limits of the Constructivist Metaphor (Springer, 2011), and Geometry as Objective Science in Elementary Classrooms (Routledge, 2010). He can be contacted at: MacLaurin Building A567, University of Victoria, Victoria, BC, V8P 5C2, Canada. Email: mroth@uvic.ca 


\title{
Introduction
}

\begin{abstract}
The relation of thought to word is not primarily a thing but a process, a movement from thought to word and back-from word to thought. This relationship represents, in the light of psychological analysis, as a developing process, which moves through a series of phases and stages and undergoes all those changes that, due to the essential characteristics, may be called as development in the true sense of this word (Vygotskij, 2005, p. 962).
\end{abstract}

The purpose of this article is to articulate a model of cognition, thinking and speaking, and its grounding in cultural-historical activity theory (A. N. Leont'ev, 1983), dialogism (Vološinov, 1930), social psychology (Vygotskij, 2005), and psycholinguistics (A. A. Leont'ev, 1969/1971; Mikhailov, 1976). The model is intended to provide a framework for scholars working in different European countries and root languages for the translation and integration of discourses all too often difficult to make because of linguistic boundaries and differences. Whereas scholars already recognize the integral relation between communication and cognition (e.g., Sfard, 2008), neologisms such as "commognition" may not at all be required given that the field has inherited a common framework for understanding communication as cognition. Moreover, the commognition framework lacks some essential features for understanding cognition that are already present in its historical antecedents. What is more, the model integrates ideas from scholars that are sometimes placed in opposing camps: Vygotsky, grounded in dialectics, and Bakhtin, emphasizing dialogue.

Although assigned to different camps, Vygotsky and Bakhtin do not appear to be so far apart on many issues. In a section of Thought and Language (Vygotskij, 2005) where the scholar focuses on the changes of signification in the living process of verbal thinking, he provides a description of a continuous coming and going that relates two processes, thinking and speaking, themselves manifestations of a higher process, word-signification [značenie slova]. Vygotsky does not say that one of the processes constitutes a dialectical inversion of the other; instead he emphasis the back and forth between the processes. This back and forth itself is a developing (rather than constant) process. As a result of this coming and going, a thought, which begins as something vague, develops into a fully articulated idea. The word, for Vygotsky, is not an expression of thought; rather, thought becomes itself only in speaking, with the word. This is to say, in Vygotsky, speaking, the voice, never is cut off from the idea. And this is fundamentally the position Bakhtin expounds generally but specifically in the work dedicated to the Russian author Dostoevsky: The idea, in Dostoyevsky, never is cut of from the voice" (Bakhtin, $1929 / 1994$, p. 177). The idea develops out of the dialogical relation of voices. In this initial sketch, we therefore see the same fundamental idea underlying the way in which Vygotsky and Bakhtin conceive of the relationship between thinking and speaking.

It has been suggested that the educational research literature has forgotten the legacy of L. S. Vygotsky - the role of his work in shaping cultural-historical activity theory (Roth \& Lee, 2007). But, I suggest here, much more has been forgotten: The fundamental commonalities that exist between his work and the work of the circle around M. M. Bakhtin (including V. N. Vološinov and P. N. Medvedev). There are scholars who dispute these commonalities (e.g., Matusov, 2011), which, because it is cutting off an important voice, leads to a missing out on the implications thereof for educational research and the study of learning, cognition, development, personality (identity), motivation, interest, and so on. Rather 
than expounding on the incompatibility of the ideas and theories that were developed, on the one hand, in the social psychology founded by Vygotsky and A. N. Leont'ev, and, on the other hand, among those scholars emerging from literary theory in the Bakhtin circle, we might be better off allowing their voices to speak to each other ${ }^{1}$. Perhaps because of the view that these sets of ideas and theories do not sit together quite easily, there appears to be little development-generating dialogue between the two strands. This position may have been substantiated by a most cogent analysis of the ontological differences between the dialectical position of Vygotsky and the dialogical position of Bakhtin (Wegerif, 2008) ${ }^{2}$. That study provides textual evidence that apparently points to a monologic ontology of Vygotsky, which, if this were the case, would be positioned diametrically opposite to the fundamentally dialogical position that Bakhtin espouses. However, the article considerably underestimates the role of societal relationsalways two-sided phenomena-in the work of Vygotsky and his recognition that every beginning is dialogical. Moreover, the ever-changing overarching process that Vygotsky denotes by "wordsignification ${ }^{3}$ [značenie slova]" (Vygotskij, 2005) is a continuous coming and going between the two everchanging processes of thinking and speaking ${ }^{4}$. His fundamentally Spinozist position "was not understood by the majority of his followers," so that it is "especially sad and tragic" that it "was never developed by the author himself" (Mikhailov, 2001, p. 19). The result of it would have been a theoretical framework that recognizes a single process of mutual generation and determination of self and other: "For the very existence of mind is possible only at the borderline where there is a continual coming and going of one into the other" (p. 20, original emphasis). Thus, Vygotsky's "work coincided in no way by accident with revolutionary breakthroughs in the theory of language . . . and in the theory of verbal creativity (M. M. Bakhtin)" (p. 15, emphasis added).

\footnotetext{
${ }^{1}$ Within the text, the names of Russian authors are spelled as is common in English; in-text references use the name as it appears on the book title or in the scholarly form of the Romanization of Russian. Russian words in the text also use the scholarly form (e.g., š for $w$ instead of sh, č for $ц$ instead of $\mathrm{ch}$ ).

${ }^{2}$ Much is being said about Bakhtin's own statements concerning the incompatibility between dialectics and dialogism. This article is not the place for developing a full argument that Bakhtin himself did not truly appreciate dialectics and its underlying commonality with his ideas denoted by the adjective "dialogic." It may be noted parenthetically however that in one of his examples, Bakhtin (1929/1994) opposes two contradictory statements, "Life is good" and "Life is not good" (p. 183 in the English translation). He suggests that these statements constitute logical, dialectical oppositions between which there cannot be a dialogue. Bakhtin does not appear to realize that neither Hegel nor the most eminent specialist on dialectical logic, E. Il'enkov, would have expected there to be a dialogical relation. A logical contradiction is an external contradiction, not a dialectical relation of an internal contradiction (Il'enkov, 1974). In dialectics, there cannot be a relation between things that are external to each other. Thus, in dialectics, the point "is not to reduce an external contradiction to an inner one," which is exactly what Bakhtin does in his example, "but in deriving the former from the latter and thus to understand both in their objective necessity." Chapter 2 of Dialectical Logic (ll'enkov, 1974) would be especially instructive to readers interested in pursuing these ideas. Most likely, Bakhtin is confusing the internal contradiction of a thing with the external contradiction between its manifestations. Physicists, too, made this confusion until the advent of quantum mechanics, when they opposed the wave and particular manifestations of light (e.g., Sève, 2005). Wave and particle cannot be just stuck together "in the same statement" to lead to a dialectical model. The unit lies elsewhere-in the quantum mechanical formulation-and the wave and particle characters are but external manifestations of the inner difference of the phenomenon of light with itself. Physicists talk about the "complementarity" of the two descriptions, which is also the developing theme of the conversation involving the three physics students reported here.

${ }^{3}$ The Russian značenie often is translated as "meaning." "Meaning," however, is a highly problematic word not in the least because more than 20 different "meanings of 'meaning'" have been identified (Nöth, 1990). Moreover, from a pragmatic perspective, the going usage of the term frequently is more consistent with a primitive understanding of the way language functions (Wittgenstein, 1953/1997) so that it may just as well be stricken from use (Wittgenstein, 2000). In this article, I follow the conventions of many translators to use the following English, German, Russian, and French equivalence: signification <> Bedeutung <> značenie <> signification (see Table 1).

${ }^{4}$ In this article, I draw on original works where possible. There is great variation in the quality of these translations, and not all of them do justice to the original. Thus, the German translation of a Vygotsky text, published in different versions entitled Thought and Language and Thinking and Speaking, corresponds much more closely to the original than the two English versions (which omit many passages). The French translation of a book originally published under the name of Vološinov-Marxism and the Philosophy of Language - but also attributed to Bakhtin (French publication) is considered far better than the English translation (which, again, implements many modifications).
} 


\section{Dialogical relations in conversation: A concrete case}

There is little research that integrates Bakhtin's dialogism and Vygotsky's cultural-historical position-although there has been at least one attempt to bring together cultural-historical activity theory and dialogism (R. Engeström, 1995). Another scholar, while recognizing the importance of the cultural and historical in Vygotsky's work, goes a different route emphasizing the "social" rather than the "societal" in the line of work that Vygotsky legacied (Wertsch, 1994). Those scholars who do employ culturalhistorical activity theory-especially as it has been presented in the West through the work of $Y$. Engeström (1987)—rarely produce the kinds of analysis that are typical for those interested in linguistic aspects that are the focus of the Bakhtin group. The reverse is also true-as exemplified in the studies by Ford and Wargo (2012), Olry-Louis, Capucine, and Pouliot (2012), or Solomon (2012). An ethnographer interested in these issues would find that there are also differences in the cultural practices of those who conduct sociological or social-psychological or discursive psychological analyses and those interested in purely psychological analyses (conceptual frameworks, conceptual change). As a result, we have two (perhaps three, if the ideas of Bakhtin and Vološinov are held to be distinct) largely disconnected frameworks that appear to have very little in common and that do not appear to relate each other. Not only are there deep relations between these works, but also that these relations may be the truly forgotten legacies of both traditions. Most important, perhaps, is the fact that those who draw on Bakhtin do not tend to use a form of data analysis consistent with the dialogical presuppositions in the work of both scholars.

To ground the proposed model concretely, let us take a look at the following apparently innocuous fragment from a concept-mapping session in a high school physics class. It exhibits some fundamental features that must not be omitted from analytic consideration given the importance of the common features in the theories of Vygotsky and the Bakhtin circle.

Early on in a concept-mapping session, where three 12th-grade physics students (Ken, Miles, and Ralf) establish the semantic relations between 16 concept words from quantum theory, we observe an exchange that consists, apart from an unrelated statement about some other aspect of classroom life, of three iterations of the same one-word locution.

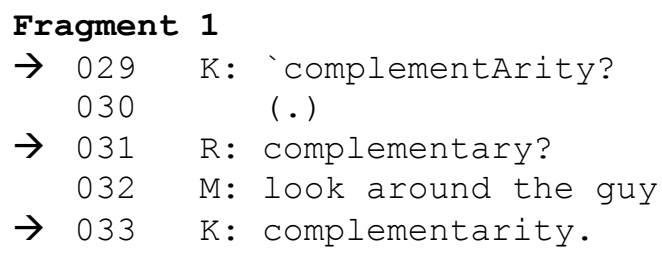

In this fragment, we observe (hear) three occurrences of the same sound-word, twice in noun form (turns 29, 33), once as adjective (turn 31$)^{5}$. We may ask what this "means," what the purpose/function is in the conversation, or whether the signification of the word changes/remains the same? Let us take a closer look. The question mark in turn 29 indicates that the pitch (intonation) is rising toward the end of the locution, which is typical for the first part of question-reply pairs. The second part of the pair contains the same sound-word also with rising pitch. That is, a question would have been followed by another question. In turn 33, we find a second part to the offered question in turn 31 . It

${ }^{5}$ Turn 32 is part of parallel conversations that these students have at the time, about having been playing sports, sweating, and racism. Interested readers will find extensive, Bakhtinian analyses of these conversations elsewhere (Roth, 2009). 
consists of the same sound-word but this time articulated with falling pitch (indicated by a period “."), as this is typical for constative statements. We may gloss a possible hearing of this conversational fragment in this way:

- What is complementarity?

- Are you asking me about complementary?

- Yes, I am asking you what is complementarity.

In this situation, we have what conversation analysts refer to as a repair sequence. It is part of a larger conversation, itself integral to the task at hand: produce a concept map using given concepts inscribed on paper slips. This task, as task, is itself situated within a larger activity relevant to society: its reproduction (Roth \& Lee, 2007). To understand what is going on in Fragment 1, we need to bring into the analysis - and, therefore, into the theory of speech activity - the situation: we cannot merely do a linguistic (structural, content) analysis of the words that appear in the transcribed text. From the latter perspective, nothing is happening as the same word has been said three times. But the formal properties of the word, the significations indicated in a dictionary, are actually much less of relevance here than are other aspects. Only the first aspect may be said to be about the objective signification of the word, which their task asks these students to determine through (some of) the ways in which the word can be combined into statements with the other terms that they have been provided with at the beginning of the task.

In uttering the sound-word with rising intonation (turn 29), Ken is articulating the first part of a question-reply sequence-here concerning the signification of the word (Bakhtin, 1965/1990). Ralf, in articulating the same word, both replies and raises a question; Ken, in articulating the same word, replies and thereby opens up for the continuation of the conversation, which may be the search for how to relate "complementarity" to other words. Here we observe one of the crucial roles of intonation: it tells us how we have to hear a locution-as question, statement, command, complaint, or in some other situationally relevant way. This aspect tends to get lost when researchers use their own competencies to hear something as a question-even if the interaction participants were not treating it as such-and place a question mark at the relevant place. Educational researchers further tend to neglect that Ralf is not just dumping the contents of his mind into the public forum but that he is taking up, and therefore evaluating, the preceding locution (Bakhtin [Medvedev], 1978), which is in fact the internal engine that drives the development of speech activity generally and its moments, the individual utterances (understood as an irreducible social phenomenon) specifically (Vološinov, 1930; Vygotskij, 2005). Moreover, the same locution also sets up the next contribution, which, again, constitutes a reply and evaluation. Each locution, therefore, is a constitutive and irreducible moment of two turns at talk: the turn pair it completes and the turn pair it begins ${ }^{6}$.

We observe the movement internal to the conversation: it develops as each locution spawns a reply. In fact, locution and reply belong together, because we do not understand the inner dynamic of the conversation unless we investigate how a second member of a turn pair relates to the first: a locution is a question only when there is a reply; it is an invitation if there is an acceptance; and it is an insult when the recipient expresses being hurt. Thus, the pairs 29/31 and 31/33 are different: the first pair rendering problematic what is at issue (the theme), and the second settling the issue. From the perspective that Vygotsky and the Bakhtin circle apparently have developed independently-but based on the same Marxist underpinnings - this movement is the most central aspect that characterizes life and living phenomena: activity, speaking, thinking, and individual and cultural-historical development. Ultimately,

\footnotetext{
${ }^{6}$ In holistic reasoning, the moment is a constitutive and irreducible part of a whole, which it manifests in a one-sided way.
} 
even though there appears to be said very little in terms of science content, classroom episodes such as this one are important because, in the end, they are integral and constitutive parts of the whole process by means of which students will have developed a discourse both collectively (discourse at the classroom level) and individual psychologically (such as exhibited, for example, during examinations).

Scholars who situate themselves in a "socio-cultural" tradition-frequently drawing on the work of Vygotsky, who rarely if ever used the term (Wertsch, 1994)_often explain learning and development in terms of "social' 'constructions"' in the group or at the classroom level; such constructions are said to precede the individual construction. However, if the processes of learning and development were to occur in this manner, we would not be able to understand why students (e.g., Ken, Miles, and Ralf), in the course of interacting, already use words or expressions or why in interaction they contribute to realizing higher psychological functions in a concrete manner. That is, we would not understand that in the very participation in a relation, learners are engaged in realizing psychological functions that socio-cultural scholars tend to ascribe to them subsequent to an intra-psychological construction. In the theoretical underpinning common to the Bakhtin circle and Vygotsky, however, taking and having a part in a dialogical relation with others is the origin of personal speech (ability) specifically and all higher psychological functions more generally (A. N. Leont'ev, 1983; Vygotskij, 2005). Aphoristically we may say that the relation is the higher psychological function.

Scholars who ground their work in Bakhtin (or his circle) often focus on language use but not on development at the situational, individual (ontogenetic), and cultural-historical (phylogenetic) levels. Yet there are fundamental commonalities between the Bakhtin circle and Vygotsky (A. A. Leont'ev, 1969/1971), between the psychological ideas of the latter and the linguistic ideas of the former. Understanding these commonalities is important, because the relation between the three levels is crucial for theorizing language, speech, and thought; and the flow and development of language at the individual and cultural-historical levels are the key issues to be modeled for understanding consciousness (Vološinov, 1930; Vygotskij, 2005). Thus, for example, we have to ask three questions that, from the perspective articulated here, not only are interrelated but also mutually constitute each other: How does individual development of speech capacity arise from the unfolding classroom conversation? How does the unfolding classroom conversation develop the discourse? How are the two forms of development related not only to the present state of language but also to its historical development? How are the developments of individual speech capacities and cultural-historical development of language related? In the next section, I articulate a theoretical position built on fundamentally common aspects from the work of both scholars. Details of the common conception are elaborated in the section that follows.

\section{Towards a relation-based, developmental theory of thinking and speaking}

As a learning scientist, I am interested in understanding the relation between thinking (idea generation) and speaking in episodes such as the one presented in the preceding section. I am interested in understanding not only what the three physics students arrive at but also how they arrive at it in and through speaking to and with each other. But I am also interested in the cultural-historical evolution of living language, which arises from the fact that people actually speak it, including students (e.g., Roth, 2013). How is language changed even while school students are speaking it? How are speaking, comprehension, productive activity, speech activity, individual language ability, and cultural-historical language related? The following model (Figure 1) emerges when the terminologies of de Saussure, Vygotsky, Bakhtin, Vološinov, A. N. Leont'ev, and A. A. Leont'ev are mapped onto the same plane. Table 1 provides the correspondences between key terms in the languages of the four scholars plus that of $K$. Marx, whose ideas are taken up and explicitly referenced by Vygotsky, A. N. Leont'ev, A. A. Leont'ev, and Vološinov. The French is important, because much of what the Bakhtin circle produced was a critical 
reaction to the work of de Saussure, which provides for the correspondences between the two languages (e.g., Bakhtin, 1979; Vološinov, 1930). The integration of de Saussure's linguistic terms and culturalhistorical activity theory (i.e., Vygotsky, A. N. Leont'ev) is provided by A. A. Leont'ev in Russian; he also provides the connections to Marx's German. The Russian, thereby, becomes the linguistic hub for making the theoretical connections between Vygotsky's social psychology, the sociological method in linguistics (Vološinov), and literature theory (Bakhtin).
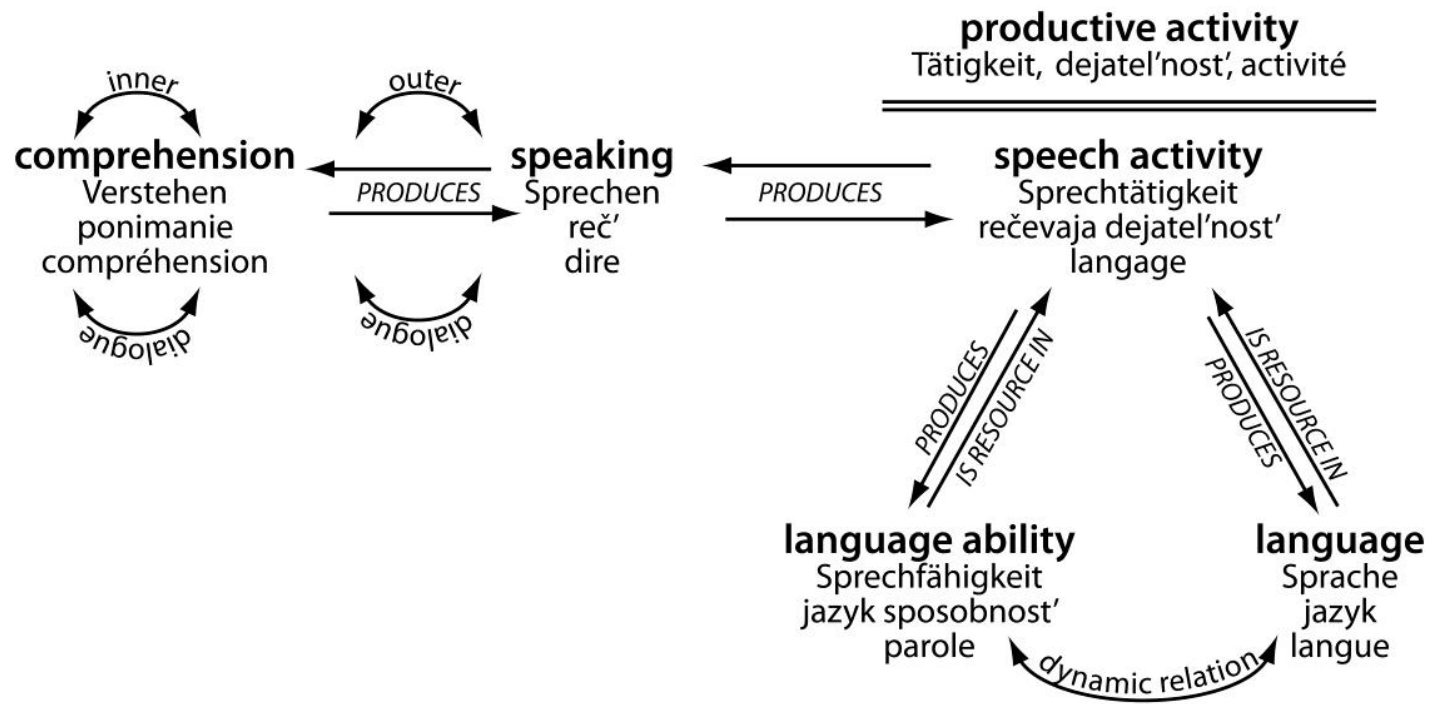

Figure 1. Model of the relation between the different components in speaking and language.

Table 1. Correspondence of Key Theoretical Terms in the Traditions of Cultural-Historical Activity Theory and Dialogism

\begin{tabular}{|c|c|c|c|}
\hline Russian & English & German & French \\
\hline $\begin{array}{l}\text { značenie } \\
\text { tema }\end{array}$ & $\begin{array}{c}\text { signification } \\
\text { theme } \\
\text { (subject, topic) }\end{array}$ & $\begin{array}{l}\text { Bedeutung } \\
\text { Thema }\end{array}$ & $\begin{array}{l}\text { signification } \\
\text { Thème } \\
\text { (sujet) }\end{array}$ \\
\hline smysl & sense & Sinn & sens \\
\hline jazyk & language & Sprache & langue \\
\hline $\begin{array}{l}\text { jazyk sposobnost' } \\
\text { (rečevix vystuplenij)a }^{a}\end{array}$ & language ability & Sprechfähigkeit & $\begin{array}{c}\text { faculté de langage, } \\
\text { parole }\end{array}$ \\
\hline reč' & speaking & Sprechen & dire \\
\hline rečevaja dejatel'nost' & speech activity & Sprechtätigkeit & langage \\
\hline soznanie & consciousness & Bewußtsein & conscience \\
\hline dejatel'nost' & activity & Tätigkeit & activité \\
\hline aktivnost' & activity & Aktivität & activité \\
\hline vyskazyvanie & utterance & Äußerung & énonciation \\
\hline $\begin{array}{l}\text { vyrašenie } \\
\text { obobščenie }\end{array}$ & $\begin{array}{c}\text { expression } \\
\text { generalization } \\
\text { (summary, abstract, } \\
\text { brief, compilation) }\end{array}$ & $\begin{array}{c}\text { Ausdruck } \\
\text { Verallgemeinerung } \\
\text { (Zusammenfassung, } \\
\text { Auswertung, } \\
\text { Idealisierung) }\end{array}$ & $\begin{array}{l}\text { expression } \\
\text { généralisation }\end{array}$ \\
\hline
\end{tabular}

aVološinov (1930) uses the term "otdel'nix rečevix vystuplenij [individual speech ability]." 
Pertaining to language, its use, comprehension, and development, everything is happening in real, affective-emotive societal relations where concrete speech activity takes place (see Figure 1). Speech activity itself is subordinated to and constitutive of activity (in the sense of dejatel'nost'/Tätigkeit), which is societally motivated, serving a generalized, collective need (e.g., Roth \& Lee, 2007). Typical activities include farming, fishing, producing instruments, and, pertinent to the present context, schooling. Activity generates and drives speech activity, which, in turn, generates and drives societally motivated activity (A. A. Leont'ev, 1969/1971): There is a mutually constitutive relation. It is precisely here that we find the utterance, a phenomenon that integrates interlocutors: speakers and listeners. The three physics students are realizing the activity of schooling. To understand what they say we need to view it within this minimum category that retains the qualities of societal life as a whole. When the students speak, they do not only change their own language ability but also language as a whole-as amply documented in a recent study of Swiss students' talk about technology (Roth, 2013).

Speech activity is concretely realized through speaking and replying, which is based on comprehending, including that of the speaker who comes to know his/her thought (after the fact) in the expressions used (Merleau-Ponty, 1945; Vološinov, 1930; Vygotskij, 2005). Again, there is a mutually constitutive relation, as speaking concretely realizes speech activity, but is produced in the service of the latter. In a conversation, there are interlocutors, who not merely externalize what is their own but who speak for the others using language that is not their own but has come to them from the other (Derrida, 1996). To properly understand the phenomenon of speaking in the episode of the preceding section, it needs to be analyzed from the perspective of hearing, which implies comprehension. Every time that the word "complementarity" is said in the episode, it is also heard; if it is not heard, then it will not affect the development of the conversation. Hearing and comprehension go together: "I hear you" also is an expression that I comprehend the other. This comprehension is not simply the reception of a signal, as in information processing theories, but it is a dialogical process on the internal plane (Vološinov, 1930); and, in fact, all speaking has its genetic origin in dialogical speech (Vygotskij, 2005). But that hearing is simultaneous with speaking does not tend to get theorized in research focusing on language use in classroom. Yet we need such a focus because inner dialogue is the psychological reflection of outer dialogue, where it has its origin both at the cultural-historical (phylogenetic) and individual developmental (ontogenetic) levels. Mikhailov (2001) summarizes Vygotsky's position on language: "the subjective reality of an inner voice, born of its externalization for the Other, and thus also for oneself as for the Other within oneself" (p. 17, original emphasis).

The generative role of speech activity in societal relations is shown in the model as the arrow from speech activity to language ability, whereby participation in the former is the origin of the latter. At the same time, language ability is a requisite in speech activity. To speak about complementarity of wave and particle in the theory of light, the three physics students require language ability; but such language ability arises in speech activity. The relation between the two is therefore constitutive. The same type of constitutive relation exists between (everyday) speech activity and language. Any change in languageeveryday (Bakhtin, 1979, 1981), scholarly (Husserl, 1939; A. A. Leont'ev, 1969/1971; Mannheim, 2004), and aesthetic (Bakhtin, Rabelais) - emerges in and arises from the common speech activity in societal relations, becoming a feature of language as a structured system. Simultaneously, there is always already language that serves as a resource in speech activity. As a result, we obtain a relation between language ability and language: "The relation between language as a societal phenomenon and language as a psychological phenomenon, between language as a system and language as a capacity is a dynamic relation, which manifests itself in the mutual transitions of the phenomena" (A. A. Leont'ev, 
1969/1971, p. 61). In cultural-historical terms, speech activity is the category that sublates and therefore mediates the two, each of which is a (one-sided) manifestation of the overarching whole.

\section{Contextualizing and elaborating the model}

In this section, I articulate and elaborate on several theoretical underpinnings that appear in the works of Vygotsky and the Bakhtin circle and are implemented in the model (see Figure 1). In the following, I discuss the commonalities under the aspects of (a) sensual life as integrative unit; (b) the selfmovement of life, entailing its and society's (cultural-historical) evolution and individual development; (c) the nested relations between activity (dejatel'nost'), speech activity (rečevaja dejatel'nost'), and the living utterance, and social intercourse (relations); (d) signification, generalization, and comprehension; (e) the role of the vernacular as locus of cultural-historical and individual genetic development; and (f) unit analysis as the methodological consequence of a holistic approach to human knowing, learning, development, thinking, and speaking. The discussion of these dimensions elaborates the model proposed in the preceding section.

\section{Sensual, affective life activity as holistic, integrative unit}

To understand a classroom situation such as the conversation of the three physics students, we require a more expansive unit than this is normally done. This unit is schooling activity, which is realized by, and constitutive of, the speech activity that we observe. As an extensive study showed, there are in this class as in any other class dimensions that exhibit the sensual, affective life; but these aspects, as a Bakhtinian analysis shows, have been and continue to be suppressed (Roth, 2009). Affective expressions, bodily functions, humor, and other dimensions characteristic of everyday life are integral to what we know as schooling activity. Undergirding the efforts of Vygotsky and the Bakhtin circle is the attempt to establish holistic theories of cognition, language, life, and personality, where "the relation [between intellect and affect] 'is not as a thing but a process'” (A. A. Leont'ev, in Vygotskij, 2005, p. 13):

Actual act-performing thinking is an emotional-volitional [èmocional'no-volevoe] thinking, a thinking that intonates, and this intonation permeates in an essential manner all moments of a thought's content. (Bakhtin, 1919/1993, p. 34, original emphasis)

The one who begins by separating thinking from affect forever closes the way to an explication of the causes of thinking ... and makes conversely also impossible the investigation of the reverse action of though on the affective-volitive side [affektivnoj, volevoj storony] of psychological life. (Vygotskij, 2005, pp. 678-679)

Both scholars agree that the word in consciousness, indissociably fused with affect, is impossible for one individual but a reality for two persons. When the analysis of speech focuses solely on the semantic aspects of speech, the emotive-affective moments of speech, "its charm, its sacred, authoritative character has become lost" (Vološinov, 1930, p. 79). This also means that the purely formal analysis of speech performance "is incompatible with a historical and living understanding of language" (p. 79). Thus, whereas there is recognition on the part of Vygotsky and the Bakhtin circle of the formal aspects of language and its relation to thinking, a true understanding of both requires situating the analysis in the fullness of life, where real people think and speak oriented by their interests, motives, and needs. The fullness of human life is expressed in society; and productive activity-which includes leisure, a form of consumption-is the minimum unit of analysis (Figure 1). It is only in the context of a societally relevant activity that we can make sense of speech activity. 
The underlying relations in the work of the two Russian scholars derive from their common Marxian underpinning of life as realized "in human sensual activity, praxis" (Marx/Engels, 1958, p. 533, original emphasis, underline added). Thus, the essay on the philosophy of language bears Marx's name in its title (Vološinov, 1930). The preface to the German translation of Leont'ev (1983) states "that the Marxist foundation of Leont'ev's psychological conception is not . . . merely an outer lip service and ideological accessory that could be left out without changing the substance" (p. 6). Rather, this foundation "constitutes the theoretical and methodical foundation . . . that alone makes [the theory] intelligible" (p. 6). In Vygotsky's text on the crisis of psychology, there are 151 [130 in the English version] references to Marx, including that psychology needs "to create its own Das Kapital" (Vygotskij, 2005, p. 173) and that this work "is written by the method" (p. 160) to be used in psychology. His fundamental idea of a concrete human psychology is based on the Marxian concept of the social nature of personality as the "set of societal relations [sobokupnost' obščestvenn'ix otnošenij]” (Vygotskij, 2005, p. 1028, original emphasis) and the societal relation as the locus and genetic origin of higher psychological functions. The name of Marx does not merely figure in these works (as Wegerif, 2008, recognizes): he articulates the very nature of the materialist dialectical categories. Unrecognized by many Western scholars is the fact that the dialectical approach is fundamentally dialogical because based on the same form of "living unresolved antagonism [čušoj nerazrešennyj antagonizm]" (Il'enkov, 1959, p. 245) that characterizes dialogism, where "the other's words are treated antagonistically [čušoe slovo ottalkivajut]" (Bakhtin, 1929/1994, p. 95) leading to a "dialogue of 'conflicting truths"' (Bakhtin, 1984, p. 75). In fact, the dialectical and the dialogical approach both model exactly the same phenomenon: change in itself rather than through outside forces, as shown below in the subsection on movement, evolution, and development. The source, in the dialectical and dialogical formulations, always is an "inner conflict [vnutrennij konflikt]" (Bakhtin, 1929/1994, p. 432), "internal contradictions [vnutrennij protivorečija]" (Bakhtin, 1929/1994, p. 233), and "internal contradictions" [vnutrennego protivorečija] (Il'enkov, 1959, p. 245) that drive the "inner stages of development" (Bakhtin, 1929/1994, p. 233-234) that drive "development through inner contradictions [razvitie čerz vnutrennij protivorečija]” (Il'enkov, 1959, p.270).

\section{Activity, speech activity, social intercourse (relations)}

Language lives and historically evolves in concrete verbal communication/ intercourse, neither in the abstract linguistic forms of language nor in the individual psyche of the speakers. (Vološinov, 1930, p. 98, original emphasis)

In the exemplifying episode, we see the conversation unfold. The three physics students manage their relations, and simultaneously are subject and subjected to these relations, by speaking and using language. Their speaking does not only have one or more topics but essentially produces the relations that also are the conditions under which the activity unfolds. For example, in the little episode, they also ascertain that they are "on the same page" concerning what exactly they are talking about, here complementarity. That is, they are not just talking content; they realize schooling generally and the current task specifically.

In education generally and in mathematics and science education specifically, one can notice an orientation toward the content aspect of speech. Thus, educational research focuses on what is said in classrooms or on what research participants say during (clinical) interviews. This content is used to make inferences about the contents of mind (i.e., conceptions, beliefs, or interests). Very little, if any, attention is given to the fact that speech is above all in order to get the attendant work done and to its role in the making of the societal situation (but see, e.g., Roth, 2008). Speech activity and intercourse, which realize 
the societal activity at hand-rather than the content of speech-are the points of departure for understanding speaking, on the one hand, and language (ability) and their development, on the other hand (see Figure 1). Speech activity is the beginning and end of language in the theories of Vygotsky and the Bakhtin circle: without speech activity, language is dead (Bakhtin) and there is no individual (cognitive) development (Vygotsky). It is important to know whether speech activity realizes educational research, schooling, or a leisure activity such as an informal visit to a science museum. Before it is about something, speaking is a means of intercourse in societally specific, productive activities that serve a generalized collective need: "The original function of speaking is communication. Speaking is first a means of social intercourse, a means of utterance and understanding" (Vygotskij, 2005, p. 675). Language as a living phenomenon, which develops on both cultural-historical and individual-ontogenetic grounds, exists only in concrete verbal communication and intercourse, as Vološinov states in the introductory quotation to this subsection. It is only in the role of the word in living relations that we can come to understand its role in communicating and thinking: "K. Marx said that it is only when articulated in the word that a thought becomes real for another and, in parting, to oneself" (Bakhtin, 1979, p. 306). Moreover, it is in concrete speech activity that we find the evaluative moments of the utterance and its uptake on the part of the interlocutor, which are unavailable in the text itself but are rendered public and are communicated by means of intonation and other non-verbal communicative dimensions (Bakhtin [Medvedev], 1978).

Speech activity, itself an integral and constitutive aspect of productive (societally motivated) activity, is the hub that mediates between the individual psychological and the societal dimensions of speech. It inherently and irreducibly is a collective phenomenon, concretely realized in speaking/actively receiving (understanding). Genetically, speech activity is the origin of both speech capacity and language (see Figure 1). The developmental and evolutionary changes in both, however, derive from speech activity, the actual process of speaking, in the concrete utterance (Vološinov, 1930). Speaking, therefore, is "a means of social intercourse, a means of utterance and understanding [sredstvo vyskazyvanija $\mathrm{i}$ ponimanija]" (Vygotskij, 2005, p. 675, original emphasis). This is why the psychologist notes at the end of his chapter on thinking and speaking that the word is impossible for the individual but a reality for two. The important dimension of speech activity is its situatedness so that speaking is a function of the situation, of concrete praxis oriented toward the realization of an object/motive [predmet] (A. A. Leont'ev, 1969/1971). It is in speech activity that the sense (smysl, for Vygotsky; tema, for Vološinov) of the word, a moment of language, is realized and that the latter depends on. Within language, there are in fact stable significations (značenija) given by dictionary definitions. But these do not tend to be relevant in speech activity and the pertinent societal relations: sense (smysl) or theme (tema), however, is the relevant issue. The stable signification (značenie) is the lower limit of a word's signifying capacity, whereas the theme is its upper limit (Vološinov, 1930).

The word is part of a living societal relation and can be understood as such. Therefore, "the nervous center of every utterance, every expression, is not at the interior but exterior: it is situated in the social milieu that surrounds the individual' (Vološinov, 1930, p. 95, original emphasis). For Vygotsky, too, the societal relation is the center of everything specifically human. It does not therefore surprise that to him every higher order psychological function has been a relation in, and constative of, society. He insists on the irreducible relation between the physical sound, which is the object of phonetics, and signification, which is the object of semantics. The result of the traditional separation between the two areas led to the fact that phonetics fails to understand what makes certain sounds specifically human, that is, specifically psychological in character. On the other hand, signification became separated from the physical sound and led to the study of the pure act of thought, which somehow was said to exist independently of the "material carrier [material'nyj nositel']" (Vygotskij, 2005, p. 672). The fruitlessness and futility of classical 
semantics and phonetics derives from the fact that these fields separate the material sound and signification, that is, that they decompose the word into elements-as physical chemists might decompose water into hydrogen and oxygen. Using the decomposition of water as an analogy, Vygotsky suggests that a theoretical understanding of the word gets lost when its material basis is separated from signification just as with the properties of water when we look at hydrogen and oxygen ${ }^{7}$. The inseparability between the material and the ideal, between the societal and the psychological, is one of the fundamental characteristics of Vygotsky's approach. He understands "development as a process characterized by the unity of the material and psychological, the unity of the societal [obščestvennogo] and the personal, in the child's ascent of the steps of development" (Vygotskij, 2005, p. 11, emphasis added). It is precisely because speech has two related moments, an inner semantic movement and an outer grammatical movement, that we can understand not only the development of thinking in situation but also the development of thinking in the child and in society.

In the first subsection, I suggest that Vygotsky, as Bakhtin, is ultimately interested in continuously unfolding life. The word is part of life, integral part of speech activity that is a moment of societal activity as a whole (Figure 1); and it is therefore living only when it is used. In fact, "the word is a living unit of sound and signification" (Vygotskij, 2005, p. 672). It is through signification in and with respect to the situated, concrete speech activity that concrete sound and ideal thought come to be united. In this way, we overcome the problem of the gap between knowledge and application that is pervasive in educational research literature. In the real speech setting, the uptake of the speech of others is critical for the further development of the former. The dehiscence in situated signification (sense, theme) between articulation and uptake constitutes change and movement. Thus, "authentic active comprehension already contains the embryo of a response. Only active comprehension allows us to comprehend the theme, for evolution can be apprehended only by evolution itself" (Vološinov, 1930, p. 104). Speech activity relates the word and its comprehension, because, when we investigate the function of the word in living speech, it is a feature of the relation of the interlocutors and therefore cannot be reduced to speaker or recipient. This is why thinking needs to be theorized from this relation rather than the relation from individual thinking. Even for the individual speaker, the recognition of the thought follows speech rather than preceding it. Thus, "in its structure, speech is not a mirror-like image of the structure of thought" (Vygotskij, 2005, p. 964). Speech does not serve the externalization of thought: "Thinking does not express but accomplishes itself in the word" (p. 964). The position in the Bakhtin circle on the relation between thinking and speaking is precisely the same: "It is not mental activity that organizes expression, but, to the contrary, it is expression that organizes mental activity, which models it and determines its direction" (Vološinov, 1930, p. 86). Thus, speaking brings thought to life but, in the process, changes it: "as thought changes into speech, it restructures itself, changes" (Vygotskij, 2005, p. 964).

\section{(Self-) movement, evolution, development}

Only this whole act is alive, exists fully and inescapably . . is an actual living participant in the ongoing event of Being. (Bakhtin, 1919/1993, p. 2, original emphasis)

In the episode from the physics course, the conversation apparently develops on its own. There is no external force that moves the activity from one stage to another. Rather, each contribution is both

\footnotetext{
${ }^{7}$ This analogy may actually be used to understand a differentiated position on dialectics and dialogism. Mixed in a single container, the elements oxygen and hydrogen - gases at room temperature - stand in an external relation in the same way as the statements "Life is good" and "Life is not good" "united in a single statement of a single subject" (Bakhtin, 1929/1994, p. 397). They do not communicate with each other. It is only within the ("dialogical") relation of the water molecule that oxygen and hydrogen explain water (e.g., the polarity of water molecules, surface tension, water droplet formation, or heating of food in microwave oven).
} 
generated by and generates the speech activity. In fact, the individual contributions are not the appropriate unit of analysis. Because the conversation is a social phenomenon, the appropriate category (minimum unit) has to be a social one (Durkheim, 1919). Life generally and society through which the specifically human life form is realized particularly are self-moving phenomena. Language, too, is such a phenomenon: as long as it is spoken, it lives and therefore changes. Once a language no longer is spoken, it is a dead language and inherently does not change. Both Vygotsky and Bakhtin are interested in self-moving phenomena and, therefore, in evolution and development.

In educational and psychological theories, change (i.e., learning, development) occurs because of forces external to the thing that changes (Lave, 1993); and thought is treated as separated from life, making it appear as if it was thinking itself (Vygotskij, 2005). In the work of Vygotsky and the Bakhtin circle, however, self-movement and development of societal life, a network of human activities (A. N. Leont'ev, 1983), is the source of all change. "Human activity [dejatel'nost' čeloveka]," the overarching, integrated unit in Figure 1, "is a process in a system of relations . . that realizes the societal nature of man" (p. 170, emphasis added). In Figure 1, mutual constitution and process, as evident in the works of Vygotsky and Bakhtin/Vološinov, are implemented in all relations of neighboring terms and levels.

In Vygotsky's work, human development generally and the development of language ability specifically is central (bottom left, Figure 1). In the work of the Bakhtin circle, the development of language and life is of central interest (bottom right, Figure 1). In the novel, one of the many different forms of the utterance, we have a perfect example: "Every novel depicts a 'self-developing life,' 'recreates it.' This self-development of life is independent of the author" (Bakhtin, 1929/1994, p. 185). The idea comes out of the tradition of Hegelian and Marxian thought. The latter constructs, in the value characteristic of a commodity, a fundamental unit that models the historical evolution of economy. To model development that comes from within a system (life, society) - that is, self-determination [samoopredelenie]—the most fundamental category has to be one of change itself (Il'enkov, 1974). But a unit of change embodies an inner contradiction that manifests itself in outer contradictions-both in the social world (e.g., each commodity in an exchange being use-value and exchange-value simultaneously (Il'enkov, 1974)—and in the material world (e.g., light exhibiting particle and wave character). In Bakhtin, the two voices within speech activity play the role of the two antagonistic poles within the same unit of dialogue; in Vygotsky, the mutually constitutive processes of thinking and speaking-for example, between adult and child-constitute the development of the same unit of word-signification in situation, in ontogeny, as in phylogeny. To model the mutually constitutive moments of cultural history and individual development, Vygotsky, in a chapter on the crisis of the psychological sciences, therefore suggests that psychology needs its own Das Kapital (Capital) that has psychological equivalent concepts of class, value, commodity, basis, interest, and superstructure. These very same concepts are brought into the philosophy of language by the Bakhtin circle (Vološinov, 1930).

In his foreword to the Russian collection of Vygotsky's key works, A. A. Leont'ev highlights the "dynamic, process character of consciousness" (Vygotskij, 2005, p. 9, original emphasis) as their core feature. Process also is central to the work of the Bakhtin circle, both with respect to the development of signification in societal interaction (Vološinov, 1930) as well as in a broader conception of life and activity (Bakhtin, 1919/1993). The non-coincidence of the material (phasic, syntactic) and semantic dimensions of the word, represented on the left in Figure 1, is "a necessary condition for the realization of the movement from thought to word" (Vygotskij, 2005, p. 967). For the Bakhtin circle, the non-coincidence of signification in speaking and active listening (found on the left in Figure 1) constitutes the fundamental, inner difference in the utterance that is required for understanding the movement of the dialogical process. It is precisely the dialogue - that is, the interaction of different voices, even if it occurs in the same mind-that 
produces the movement of thought (Bakhtin, 1929/1994); it is precisely the inner difference within each of the two commodities in a commodity exchange that produces the movement of economy (Il'enkov, 1959). For Vygotsky, ideas (themes) are unfolding, evolving, and developing (a movement) because of the double movement of thinking to speaking and speaking to thinking, whether the dialogue occurs between real people or internally between two voices in the same mind. Thus, "the relation of thought to word is above all not a thing, but a process - the movement from thought to word and, reversely, from word to thought" (Vygotskij, 2005, p. 963).

Thought is a process by means of which a task or problem is solved: thought accomplishes work. The development of thought is an inner movement, across a whole series of planes, a transition of thought into word and word into thought. For Bakhtin, novels, ideas, conversations, and ideas develop because of different voices that "listen to each other constantly, call back and forth to each other and are reflected in one another" (Bakhtin, 1929/1994, p. 283). This work is an integral part of practical activity, itself constituting and constituted by speech activity. Because practical activity is in the service of sustaining society and human life, evolution, development, and history never end, or life would be at its end (Bakhtin, 1919/1993). Bakhtin refers to open-endedness and unfinalizability, which finds its appropriate model in the dialogue in which the self-other relation, its unity and differentiation, is produced and "draw into the movement of a perpetuum mobile, as are all anticipated replies" (Bakhtin, 1929/1994, p. 162).

In the integrated model (Figure 1), we come to theorize the different temporal aspects to the relation between thinking and speaking or thought and language. Historically, language (bottom right, Figure 1) evolves and, thereby, provides a changing reservoir of semantic and syntactic possibilities. Ontogenetically, language ability (bottom left, Figure 1) changes, which results in a change of the relation between thinking and speaking (far right, Figure 1). This is so because the repertoires of words and situations in the experience of the child change, and because, concomitantly, the relation between the processes of thinking and speaking changes. In adult thought, the situational development of signification in speech activity (center, Figure 1) is above all a "functional development-the movement of the thought process itself from thought to word is development" (Vygotskij, 2005, p. 963). This allows Vygotsky to speak of the becoming of thought (as unit of being and non-being) in the word. Thought exhibits a movement, which seeks to establish a relation between one thing and another. It is a movement, an unfolding process, a development.

\section{Signification and generalization-comprehension}

In the conversation, the three physics students comprehend each other; and when they do not comprehend, as shown in the episode; their talking contributes to repair the absence of comprehension. Without comprehension and the associated signification, there would not be conversation and dialogue, as we know them, because speakers would talk past rather than with (con-) each other. In the model, speech activity produces and is produced by speaking and actively receiving, which are based on signification and comprehension (at left in Figure 1). Statements that attribute "meanings" to words that lie behind these words are replete in the educational research literature (e.g., in the 2011 volume of the Journal of Research in Science Education, there are 626 uses of the noun, adjectival, and verb forms of the stem "mean"). In a cultural-historical approach, such an attribution cannot be made: "There is no place saying that a signification [značenie] belongs to the word as such" (Vološinov, 1930, p. 104). For Vygotsky, the signification changes in the course of child development (ontogenesis), where the structure and nature of the connection between the word and signification changes; there are also functional changes in signification in social interaction, which make it that the same sound-word does not mean to say the same when it is uttered repeatedly in the same setting. This leads to the realization that 
signification is "not in the word, and not in the soul of the speaker, and not in the soul of the listener. Signification is the effect of the interaction between speaker and receiver, acting upon the material of a given sound complex" (Vološinov, 1930, p. 104, original emphasis).

The concrete, situated nature of speech activity has as a consequence that upper limit of signification—that is, the theme [tema] for Vološinov, sense [smysl] for Vygotskij-cannot be considered independent of the situation. As A. A. Leont'ev points out in the foreword to the Russian edition of Psychology of Human Development (Vygotskij, 2005), even before the object-oriented nature of activity became an important aspect in the theories of Usnadse, Rubinstein, and A. N. Leont'ev, Vygotsky provided the first sketch of the object-oriented nature of signification. Each person relates to the situation by means of affect, a valuative moment in communication that is communicated in and through intonation. "Intonation reveals the inner psychological context of the speaker, which determines the sense of the word" (Vygotskij, 2005, p. 996). Speaking is different from writing, because the latter has to articulate what in the oral form is transmitted by means of intonation and immediate perception of the setting.

For Vygotsky, Vološinov, and Bakhtin, therefore, situated appreciation is communicated by means of intonation and the situational determinants. Vygotsky refers to this as sense (smysl), Vološinov as theme (tema). Both quote the same lengthy passage from Dostoevsky's Diary of an Author, in which six drunken craftsmen articulate the same curse word one after the other. However, situated signification (theme, sense) changes each time the sound-word is pronounced, due to the intonation that has changed. Vygotsky suggests that it is a quintessential example of the contraction that occurs in verbal speech, where the signification is (a) available in understanding of the situation as a whole and the going theme in particular-similar to Heidegger's (1927/1977) idea of words that accrue to rather than having significations, and (b) where intonation expresses "the inner psychological context of the speaker" (Vygotskij, 2005, p. 996). Both moments are integral to situated signification (sense, theme).

Analyzing the same situation, Vološinov suggests that the word constitutes but the material support for the intonation, which really expresses the situated signification (theme [tema]). In all six utterances of the craftsmen, "the theme inherent in every utterance (because the utterances of each of the six craftsmen has its own theme) realizes itself entirely by the sole means of the intonation" (Vološinov, 1930, p. 106). The dictionary signification is, here, entirely irrelevant, and the understanding of what is going on and communicated about comes from somewhere else: the situation. Thus, "the appreciations and the corresponding intonations are entirely determined by the immediate social situation" (p. 106). In speaking, there is therefore a real dialectic at work between more or less stable historically evolving, cultural-historical significations of a word that can be found in dictionaries, and the current theme, the relation of the word to the utterly situated, emotional-affective dimensions of concrete speech situation.

Signification is the fundamental, indivisible and therefore irreducible unit that characterizes the unity of communication and generalization/ compilation [obobščenie], that is, it characterizes whole, which, for Vygotsky, is consciousness and its relation to the material world: "Consciousness reflects itself in the word like the sun in a water droplet. The word relates to consciousness as a small to a large world, a living cell to the organism, like an atom to the universe. It is a small world of consciousness" (Vygotskij, 2005, p. 1018). Consciousness is where material reality is reflected on an ideal (inner) plane. The two planes, the material and ideal, cannot be understood independently of each other. Vygotsky points this out time and again, including in his emphasis that it is not the brain that thinks but man, who stimulates the brain by means of external, material signs. 
Signification cannot be theorized independently of generalization. Vygotsky approvingly quotes Tolstoy to say that the word is ready when the generalization (concept) is formed. Signification therefore not only constitutes the "unity of thinking and speaking but also the unity of generalizations and intercourse, of communication and thinking" (Vygotskij, 2005, p. 676, original emphasis). Moreover, generalization is a direct consequence of interaction with others: Intercourse necessarily presupposes a generalization and therefore the development of the signification of the word, that is, the generalization is enabled by the development of intercourse" (p. 676). Generalization constitutes a speech-thought act that reflects reality very differently than immediate sensations and perceptions: The signification of the word "reveals itself above all in generalization, which is contained in each word as fundamental and central moment, for every word generalizes" (p. 961). Thought reflects reality in consciousness in a qualitatively different way than immediate sensations and perceptions.

Generalization, as Vygotsky describes it, derives from the fact that in communication of something, a feeling, belief, or content of consciousness, there is no other way than attributing the content to a class of phenomena, which necessarily requires generalization. Generalization here does not have to mean abstraction in the Kantian sense. Rather, consistent with the focus on the concrete situation, we may understand generalization in the sense of the documentary method (Mannheim, 2004), where a word refers to the ensemble of situations in which it may be used appropriately. In the documentary method, each concrete instance is taken as a document or manifestation of a whole. This whole only exists in a concrete way and, therefore. In contrast to a generalization in the Kantian sense, where the overarching concept only contains what is common to all the things it combines, that is, from which the general has been abstracted consisting only of those features common to all-as in the classical concept learning paradigm by Bruner and colleagues-the overarching whole is just as concrete as all its manifestations. But the whole is not a simple sum, for there are part-whole relations such that each part, being part of the whole, also is determined by all other parts ${ }^{8}$. Applied in the present context, the generalization of the world is theorized in terms of all the concrete situations in which it is used. The word is a document of all the different situations in which it is used, all the phrases that can be made with it, all the claims formulated, and so on. This form of generalization does not abstract from the situation, nor is it the sum or the common element across situation. Rather, it is the relation between part and whole, the word being the part that refers us to all the different situations in which it finds appropriate use.

\section{The vernacular as the genetic origin of cultural-historical and ontogenetic development}

Speech activity in societal relation, the hub of the model in Figure 1, constitutes the culturalhistorical, ontogenetic, and situational origin of all language. In educational and psychological research, common knowledge and everyday vernacular are often regarded as deficient-for example, the source of "misconceptions." However, there also exists recognition of the vernacular as the fundamental basis of formal (scientific, mathematical) knowledge-among cultural-historical and scholars of other fields alikenot only on a cultural-historical (phylogenetic) level but also for individual development (ontogenesis) (Bakhtin, 1965/1990; Husserl, 1976; Mannheim, 2004; Vygotskij, 2005). Moreover, the scholars recognize that the vernacular not only is the genetic origin of knowledge and discourse but also the locus where change occurs and drives the changes in the academic and cultural fields, which reflect the changes in the broader cultural worldview or zeitgeist.

First, and based on the grounds of plausibility, any more advanced cultural knowledge has emerged from simpler forms of knowledge. Thus, for example, the Greek understanding of geometry was

\footnotetext{
${ }^{8} \mathrm{~A}$ constraint satisfaction network is perhaps the easiest way to conceptualize this relation, as the development of each and every part is determined not only by its own state but also by those of all other parts that figure into the whole.
} 
the result of increasing technical and technological refinements of everyday objects, which led to the emergence of the idea of ideal objects that were not plagued with the inaccuracies and differences of actual material objects (Husserl, 1939). The emerging new forms of (mathematics-related) speech activity provided for relations that themselves were the origin of higher psychological functions of subsequent generations, such as cultural-historical scholars describe them and provide examples for (Meshcheryakov, 1974; Vygotskij, 2005). Because children first and foremost find themselves and develop understandings in the vernacular, it is the basis for their participation, for example, in scientific and mathematical argumentation in the school (e.g., Moje et al., 2004; Schwarz, Dreyfus, \& Hershkowitz, 2009) and, therefore, to the understandings that develop from such speech activity.

It is in popular culture that we find the ground for the changes not only in vernacular discourse and culture but also in other discourses (Bakhtin, 1965/1990). This is so because "all secondary genres (artistic and scientific) incorporate diversely the primary speech genres in the construction of utterances as well as the relation between them" (p. 251). Vygotsky, too, recognizes the vernacular as the source of "incessant movement." Thus, as a result "of its own fluctuations and non-correspondences between the grammatical and the psychological," "our common vernacular exists . . in a state of dynamic equilibrium between the ideals of mathematical and fantastic harmony, and in an incessant movement that we call evolution" (Vygotskij, 2005, p. 967). Thus, vernacular, as the root and ultimate fallback language, brings about the developmental changes in genres-for example, the evolution of the novel from Greek antiquity to the modern day —and the style in literature (Bakhtin, 1975; A. A. Leont'ev, 1969/1971). Every secondary genre is built upon, transformed by, and transforms - for example, via popularization of scientific and mathematical writing, the primary genre, the vernacular (Husserl, 1976; Mannheim, 2004). But in the process, the fragments that come from the vernacular lose, in a dialectical inversion, their vernacular characteristics. The development of language therefore requires in the totality of factors that bring about change, that is, to conduct an analysis of speech activity. Thus, language as a formal system "appears in real development of language as a form of interaction of the constituents of the developmental process-its formants, as its conditions" (A. A. Leont'ev 1969/1971, p. 60, original emphasis).

The vernacular is fundamentally dialogical, a point that is especially brought forth in the analysis of popular culture and the artistic work of François Rabelais during the Renaissance (Bakhtin, 1965/1990). Thus, the feast, laughter, and carnival all are features of the popular culture where the seriousness of life becomes dialectically inverted, and, in this inversion, it also becomes reasserted. One recent study showed that in science classrooms, laughter has the same function, because it comes with a break from the seriousness of science lessons and, in so doing, reasserts the seriousness of science, which is only interrupted by the non-serious (Roth, Ritchie, Hudson, \& Mergard, 2011). Vygotsky recognizes the "incessant movement" that comes from the vernacular and locates there the psychological origin of speaking: "from a psychological perspective, dialogical speaking is the original form of speaking" (Vygotskij, 2005, p. 996, emphasis added). This dialogical speaking is situated in the societal relations where all higher psychological functions originate. The members of the Bakhtin circle recognize societal relations as the fundamental ground upon which language rests. Thus,

the social relations evolve (as a function of the infra-structures), then the communication and verbal interactions evolve in the context of the social relations, the forms of speech acts evolve from the fact of verbal interaction, and the process of the evolution is reflected, finally, in the changes of the forms of language. (Vološinov, 1930, p. 98) 


\section{Toward unit analysis}

The Bakhtin/Vygotsky model (see Figure 1) has methodological implications: Any analysis of language use and comprehension, signification, learning, or development has to begin with (speech) activity, the smallest, non-additive unit of life of the embodied material subject (Leont'ev, 1983; Roth \& Lee, 2007). However, in the current educational research literature, as noted above, there is an almost exclusive focus on the (semantic) content of speech. Moreover, whether the analyses focus on classroom talk or on interviews, there is a tendency to identify thought and speech. But if we do so, we are no longer in a position to ask the question about the relation between the two phenomena and, therefore, fail to resolve the problem of thought and speech from the outset (Vygotskij, 2005). As a result, we simply avoid the problem or choose not to see it. Moreover, the traditional approaches to the analysis of language in situation, therefore, as the foregoing subsections make evident, do not allow us to understand the significance of what has been said. Vygotsky discusses cases where the psychological subject and predicate do not coincide with the grammatical subject and predicate. As a result of his analysis, he concludes that "we may speak not only of psychological subjects and predicates, but also, with the same right, of psychological number, gender, case, pronoun, superlative, future etc." (Vygotskij, 2005, p. 967). However, what matters to the situation is the "psychological aspect" rather than the dictionary signification of the word. This may lead to the situation that what is an error from the perspective of formal language may have productive and artistic value. This has consequences for consciousness and for the psychology of learning and development. This is quite in contrast to much educational research, where "meaning" is of primary, sociolinguistic importance (e.g., Lemke, 1990).

In the introductory chapter to his book on the relation between thinking and speaking, Vygotsky is requesting us to move from the analysis of elements to the analysis of units. The appropriate unit in the study of speaking he proposes is that of the "significance of the word [značenie slova]" (Vygotskij, 2005, p. 675). Because speaking is a means of social interaction, the word cannot be abstracted from the relation between speaker and recipient. The word must be analyzed in its functional relation to the situation. The work of the Bakhtin circle completely maps onto a cultural-historical activity theoretic approach to language (A. A. Leont'ev, 1969/1971). Thus, the scholar quotes a longer passage from Marxism and the Philosophy of Language (Vološinov, 1930) in which the following methodical sequence in the study of language is articulated:

(1) forms and types of verbal interaction in connection with their concrete conditions; (2) forms of individual statements [vyskazyvanie], in close connection with isolated speech capacities, of which they constitute elements that lends itself to a determination by verbal interaction, that is, the categories of speech genres in life and in the ideological creation; (3) from there, revision of the forms of language in their habitual linguistic interpretation. (p. 98)

This sequence emphasizes the same dimensions that are also of importance in the culturalhistorical perspective, including the "concrete conditions" (i.e., productive activity) in the context of which verbal interaction (i.e., speech activity) takes place. Individual statements and speech capacities are the converse of verbal interactions: the two mutually constitute each other.

For the Bakhtin circle, the fundamental notions concerning language constitute a complete system of irreducible and unified pairs:

recognition and comprehension, cognition and exchange, dialogue and monologue, whether they are internal or external, every sign provided with a signification and every signification attached to a word, identity 
and variability, universal and particular, social and individual, cohesion and divisibility, utterance and uttered.

(Jakobson, 1977, p. 8)

For Vygotsky, too, methodological issues arise from two key problems that require to be addressed: (a) the relationship of thought and word, and (b) the relationship of generalization and intercourse. That is, we cannot "tear" the word from the relation with other people and from the way it reflects the reality of the situation in consciousness ("generalization"). Signification, as his analysis of the episode from Dostoevsky's Diary of an Author shows, depends on the situation and qualities other than the sound-word itself, for example, on intonation.

When we are interested in the analysis of a real conversation, then each word has to be analyzed from the double perspective of the speaker and the recipient. This double perspective does not exist in the language but is a function of the exchange, which irreducibly involves multiple parties. The replies, which alternate between the participants in the exchange, are interrelated. The relations that establish themselves between the corresponding parts of a dialogue-question-response, assertion-objection, affirmation-accord, offer-acceptance, or order-execution-"are impossible between the unities of language . . . but are possible only between the utterances emanating from distinct speaking subjects" (Bakhtin, 1979/1984, p. 250). Each interlocutor presupposes the other such that the relation between the locutions cannot be grammaticalized. There is a relation between the utterances of two or more participants in a dialogue that goes beyond the word. This relation, between the proposition and context, between the utterances of the different speakers, is "mediated by the entire environing context, that is, by the utterance in its entirety" (p. 252).

This has implications for the analysis of speech activity, for example, for analyzing lessons and transcript fragments such as that provided in the introductory analysis. It is clear that this exchange constitutes an integral part of the totality of exchanges from which the conceptualization, sedimented in the concept map the students produced, emerged. Whereas research in education and educational psychology tends to abstract speech from the situation, attributing words to individuals and their mental structure (or some other attribute of the person), Vygotsky and the Bakhtin circle force us to consider the larger context: clinical interview, classroom talk, conversation in informal setting, and so on. These settings are themselves part of larger, societally relevant contexts that need to be considered to understand the form, content, and emotional dimensions of speech: it matters whether speakers participate voluntarily in research, in compulsory schooling, or a jointly planned family visit to the science museum. It is precisely this larger activity—characterized by a societal motive—that mediates how thinking reflects reality in consciousness.

\section{Coda}

In this paper, I propose a model of speaking, thinking, and the development of language at the individual and collective levels that is grounded in the work of Vygotsky and the Bakhtin circle. Realizing the compatible contributions of Vygotsky and the Bakhtin circle in one model of speaking and thinking allows educational researchers to theorize together what often is held separate: individual development of language ability and the cultural-historical, ideological (dialogical, discursive) functions of language. Existing attempts to theorize the individual and social, because of their primacy of the individual (e.g., Vosniadou, 2007), are inconsistent with both Vygotsky and Bakhtin. A coherent unified model, however, allows researchers to integrate the often-distinct sociological and psychological perspectives on classroom learning that tend to be kept separate in much of educational research (e.g., Roth, 2010). The table of correspondences (Table 1) should assist scholars from different languages in thinking the works 
of these scholars more coherently and in working with the model across language barriers. This may allow for more discussions across the different groups within the educational research community.

\section{References}

Bakhtin, M. M. (1975). Voprosy literatury i estetiki [Problems in literature and aesthetics]. Moscow, Russia: Xudoš. Lit. (English: The dialogic imagination, Austin, TX: University of Texas, 1981)

Bakhtin, M. M. (1979). Estetika slovesnogo tvorčestva [Aesthetics of verbal creation]. Moscow, Russia: Iskusstvo. (French: Esthétique de la creation verbale, Paris, France: Éditions Gallimard, 1984)

Bakhtin, M. M. (1990). Tvorčestvo Fransua Rable i narodnaja kul'tura srednevekov'ja i Renessansia [The work of François Rabelais and popular culture of the Middle Age and Renaissance. Moscow, Russia: Xudošestvennaja literatura. (Assistance from the French translation L'œuvre de François Rabelais et la culture au Moyen Age et sous la Renaissance, Paris, France: Gallimard, 1970) (First published in 1965)

Bakhtin, M. M. (1993). Toward a philosophy of the act (Vadim Liapunov, trans.). Austin, TX: University of Texas Press. (The original, K filosofii postupka, begun in 1919, is available at www.philosophy.ru/library/bahtin/post.html and lib.rus.ec/b/363950/read)

Bakhtin, M. M. (1929/1994). Problemy poètiki tvorčestvogo Dostoevskogo [Problems of the poetics in the work of Dostoevsky]. Kiev, Russia: Next. (English: Problems of Dostoevsky's poetics, Minneapolis, MI: University of Minneapolis Press, 1984)

Bakhtin, M. M. [Medvedev, P. N.] (1978). The formal method in literary scholarship: A critical introduction to sociological poetics. Baltimore, MD: Johns Hopkins University Press.

Derrida, J. (1996). Monolinguisme de l'autre ou la prothèse d'origine [Monolingualism of the other or prosthesis of origin]. Paris, France: Galilée.

Durkheim, E. (1919). Les règles de la méthode sociologique [Rules of sociological method]. Paris, France: Felix Alcan.

Engeström, R. (1995). Voice as communicative action. Mind, Culture, and Activity, 2, 192-215.

Engeström, Y. (1987). Learning by expanding: An activity-theoretical approach to developmental research. Helsinki, Finland: Orienta-Konsultit.

Ford, M. J., \& Wargo, B. M. (2012). Dialogic framing of scientific content for conceptual and epistemic understanding. Science Education, 96, 369-391.

Heidegger, M. (1977). Sein und Zeit [Being and time]. Tübingen, Germany: Max Niemeyer. (First published in 1927)

Husserl, E. (1939). Die Frage nach dem Ursprung der Geometrie als intentional-historisches Problem [The question of the origin of geometry as an intentional-historical problem]. Revue internationale de philosophie, 1, 203-225.

Husserl, E. (1976). Gesammelte Werk Band III/1. Ideen zu einer reinen Phänomenologie und phänomenologischen Philosophie. Erstes Buch: Allgemeine Einführung in die reine Phänomenologie [Collected works vol. III/1. Ideas to a pure phenomenology and phenomenological philosophy, vol. 1: General introduction into pure phenomenology]. The Hague, The Netherlands: Martinus Nijhoff.

Il'enkov, E. V. (1959). Dialektika abstraktnogo i konretnogo $v$ «Kapitale» Marksa [The dialectics of the abstract and concrete in Marx's Capital]. Moskow, USSR: Izdatel'stvo Akademii nauk SSSR. (English translation: Progress Publishers, Moscow, Russia, 1982)

Il'enkov, E. V. (1974). Dialectikičeskaja logika: Očerka istorii i teorii [Dialectical logic: Essays in its history and theory]. Moskow, Russia: Izdatel'stvo političeskoj literatury. (English: Dialectical logic: Essays in its history and theory, H. Campbell Creighton, Trans., Moscow, Russia: Progress, 1977) 
Jakobson, R. (1977). Preface. In M. Bakhtine [V. N. Volochinov], Le marxisme et ala philosophie du langage: essai d'application de la méthode sociologique en linguistique. Paris, France: Les Éditions de Minuit.

Lave, J. (1993). The practice of learning. In S. Chaiklin \& J. Lave (Eds.), Understanding practice: Perspectives on activity and context (pp. 3-32). Cambridge, UK: University of Cambridge Press.

Lemke, J. L. (1990). Talking science: Language, learning and values. Norwood, NJ: Ablex.

Leont'ev, A. A. (1969). Jazyk, rec', recevaja dejatel'nost' [Language, speech, speech activity]. Moscow, Russia: Prosveščenje. (German: Sprache, Sprechen, Sprechtätigkeit, C. Heeschen, Trans., Stuttgart, Germany: Kohlhammer, 1971)

Leont'ev, A. N. (1983). Dejatel'nost'. Soznanie. Ličnost'. [Activity, consciousness, personality]. In Izbrannye psixhologičeskie proizvedenija vol. 2 (pp. 94-231). Moscow, Russia: Pedagogika. (German: Tätigkeit, Bewusstsein, Persönlichkeit, Cologne, Germany: Pahl-Rugenstein, 1982)

Mannheim, K. (2004). Beiträge zur Theorie der Weltanschauungs-Interpretation [Contributions to the theory of worldview interpretation]. In J. Strübing \& B. Schnettler (Eds.), Methodologie interpretativer Sozialforschung: Klassische Grundlagentexte (pp. 103-153). Konstanz, Germany: UVK.

Matusov, E. (2011). Irreconcilable differences in Vygotsky's and Bakhtin's approaches to the social and the individual: An educational perspective. Culture \& Psychology, 17, 99-119.

Marx, K./Engels, F. (1958). Werke Band 3 [Works vol. 3]. Berlin, Germany: Dietz.

Merleau-Ponty, M. (1945). Phénoménologie de la perception [Phenomenology of perception]. Paris, France: Éditions Gallimard.

Meshcheryakov, A. (1974). Slepoglyxonemye deti: razvitie psyxiki v processe formirovanija pobedenija [Deaf-blind children: Development of mind in the formation of behavior]. Moscow, Russia: Pedagogika. (English: Awakening to life: On the education of deaf-blind children in the Soviet Union, Moscow, Russia: Progress, 1979)

Mikhailov, F. T. (1976). Zagadka čelovečeskogo ja (2nd ed). Moscow, Russia: Politizdat. (English: The riddle of self. Moscow, Russia: Progress, 1980)

Mikhailov, F. T. (2001). The "other within" for the psychologist. Journal of Russian and East European Psychology, 39, 6-31.

Moje, E. B., Mclntosh Ciechanowski, K., Kramer, K., Ellis, L., Carrillo, R., \& Collazo, T. (2004). Working toward third space in content area literacy: An examination of everyday funds of knowledge and discourse. Reading Research Quarterly, 39, 38-71.

Nöth, W. (1990). Handbook of semiotics. Bloomington, IN: University of Indiana Press.

Olry-Louis, I., Capucine, B., \& Pouliot, M. (2012). Confidence sharing in the vocational counselling interview: Emergence and repercussions. International Journal for Educational and Vocational Guidance, 12(1), 47-65.

Roth, W.-M. (2008). The nature of scientific conceptions: A discursive psychological perspective. Educational Research Review, 3, 30-50.

Roth, W.-M. (2009). Dialogism: A Bakhtinian perspective on science and learning. Rotterdam: Sense Publishers.

Roth, W.-M. (Ed.). (2010). ReUniting sociological and psychological perspectives. Dordrecht, The Netherlands: Springer-Verlag.

Roth, W.-M. (2013). Technology and science in classroom and interview talk with Swiss lower secondary school students: a Marxist sociological approach. Cultural Studies of Science Education, 8, 433465.

Roth, W.-M., \& Lee, Y. J. (2007). “Vygotsky's neglected legacy”: Cultural-historical activity theory. Review of Educational Research, 77, 186-232. 
Roth, W.-M., Ritchie, S. M., Hudson, P., \& Mergard, V. (2011). A study of laughter in science lessons. Journal of Research in Science Teaching, 48, 437-458.

Schwarz, B., Dreyfus, T., \& Hershkowitz, R. (Eds.). (2009). Transformation of knowledge through classroom interaction. London, UK: Routledge.

Sève, L. (2005). Émergence, complexité et dialectique [Emergence, complexity, and dialectic]. Paris: Odile Jacob.

Sfard, A. (2008). Thinking as communicating: Human development, the growth of discourses, and mathematizing. Cambridge, UK: Cambridge University Press.

Solomon, Y. (2012). Finding a voice? Narrating the female self in mathematics. Educational Studies in Mathematics, 80, 171-183.

Vološinov, V. N. (1930). Marksizm i folosofija jazyka: osnovye problemy sociologičeskogo metoda $b$ nauke o jazyke [Marxism and the philosophy of language: Main problems of the sociological method in linguistics]. Leningrad, USSR: Priboj. (Translation verified using the French translation Bakhtine, M. [Volochinov, V. N.] (1977). Le marxisme et la philosophie du langage: Essai d'application de la méthode sociologique en linguistique. Paris, France: Les Éditions de Minuit.

Vosniadou, S. (2007). The cognitive-situative divide and the problem of conceptual change. Educational Psychologist, 42, 55-66.

Vygotskij, L. S. (2005). Psyxhologija razvitija čeloveka [Psychology of human development]. Moscow, Russia: Eksmo.

Wegerif, R. (2008). Dialogic or dialectic? The significance of ontological assumptions in research on educational dialogue. British Educational Research Journal, 34, 347-361.

Wertsch, J. V. (1994). The primacy of mediated action in sociocultural studies. Mind, Culture, and Activity, 1, 202-208.

Wittgenstein, L. (1953/1997). Philosophische Untersuchungen / Philosophical investigations (2nd ed.). Oxford, UK: Blackwell. (First published in 1953)

Wittgenstein, L. (2000). Bergen text edition: Big typescript. Accessed March 8, 2011 at: http://www.wittgensteinsource.org/texts/BTEn/Ts-213

\section{(cc) EY}

Articles in this journal are licensed under a Creative Commons Attribution 3.0 United States License.

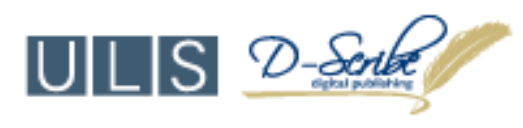

This journal is published by the University Library System, University of Pittsburgh as part of its D-Scribe Digital Publishing Program and is cosponsored by the University of Pittsburgh Press. 